\title{
Do mats matter? - Comparison of fertility traits and milk yield in dairy cows on rubber or concrete flooring
}

\author{
Prisca V. Kremer ${ }^{1,3}$, Armin M. Scholz', Stefan Nüske1 and Martin Förster ${ }^{1,2}$ \\ 'Livestock Center of the Veterinary Faculty, University Munich, Oberschleissheim, Germany, ${ }^{2}$ Chair for Animal Breeding \\ and Husbandry, Veterinary Faculty, University Munich, Munich, Germany, ${ }^{3}$ Faculty of Agriculture, University of Applied \\ Sciences Weihenstephan-Triesdorf, Triesdorf, Germany
}

\begin{abstract}
Rubber flooring in dairy cows has been discussed controversially, because different studies found as well advantages as disadvantages regarding claw health. Until today little is known regarding the effect of rubber flooring on the reproductive performance of dairy cows. Therefore, the study aimed at comparing fertility and the milk yield of dairy cows on concrete or rubber flooring. Days to first breeding (DFB), days open (DO), services per conception (SC), heat detection rate $(\mathrm{HDR})$, conception rate (first service; $\mathrm{CR}_{1 \text { st service }}$ ) and the corresponding 100 days in milk (DIM) milk yield were evaluated for 139 lactation periods of 91 cows of the University Munich Livestock Center dairy herd. The cows entered the study as heifers and were housed on the same flooring system during their whole productive life. All cows underwent the same management, feeding, and climatic conditions. A mixed model procedure was used to analyse data. Cows on rubber (RSF) compared with cows on concrete flooring (CSF) showed less DFB (76.8/94.6; $P<0.01)$, less DO (98.8/138.4; $P<0.01)$, and no difference regarding SC (1.5/1.7; $P=0.267)$. Furthermore, no differences regarding the $100 \mathrm{DIM}$ milk yield could be established. The calculation of $\operatorname{HDR}(54.9 \% / 27.9 \%)$ and $\mathrm{CR}_{\text {Ist service }}$ (39.4/29.4) showed also high advantages for the rubber flooring. It was concluded that rubber flooring affects an earlier onset of regular oestrus behaviour and improves the economically sensible fertility trait of calving interval by earlier pregnancy and less days open but does not cause higher milk yield.
\end{abstract}

Keywords: cow comfort, rubber flooring, fertility, milk yield, dairy cows

\section{Introduction}

Health and welfare of dairy cows are vitally important to ensure their longevity and longterm productivity in order to resist the high financial pressure burdening the dairy farming. The productive performance of a herd is characterised by different traits. The two most important traits, as they primarily define a cow's value and affect a farmer's decision for culling, are fertility and milk yield. Until 15 years ago, selection for breeding was mainly focused on milk yield (Leitch 1994) regardless overall health or fertility. The continuous gain of milk yield in dairy cattle breeding coincided with a global decrease in average herd reproductive performance (Nebel \& McGilliard 1993, Sørensen et al. 2007) and also affected overall-health of high yielding dairy cows (Windig et al. 2005). But only overall-health and 
fertility can ensure longevity. In contrast, longevity increases the mean herd production, because the proportion of mature, and therefore higher yielding cows is enlarged, and the farmer's decision for culling is more often made by a cow's milk yield (Allaire \& Gibson 1992). In recent years, efforts have been undertaken to improve welfare and overall-health of dairy cows by providing a higher level of comfort regarding the housing environment. These efforts firstly focused on stall design and bedding but recently, among others, also include alley flooring. Floor conditions which satisfy the cow's demand for a comfortable, yielding ground were created by fitting alleys with elastic rubber mats. Until today, however, the effect of rubber flooring in loose housing systems is discussed controversially. Research resulted in both, improvement of welfare, claw health (Benz 2002, Vanegas et al. 2006), and behaviour traits regarding activity, gait, or mounting (Kremer et al. 2007, Platz et al. 2008), as well as in worsening of the incidence of sole ulcers (Fjeldas et al. 2011), and lack of beneficial effects on oestrous expression and reproductive performance in grass-based systems during the winter months (Boyle et al. 2007). Comparison of cows housed on concrete or rubber flooring did not show any differences regarding daily average milk yield (Kremer et al. 2007), but demonstrated lower somatic cell counts in cows housed on rubber flooring (Kremer et al. 2006). Therefore, evidence is provided that soft flooring improves the welfare of cows, but - to our knowledge - no evidence is available for higher reproductive performance or milk yield until today. In consequence, this study aimed at comparing fertility traits and the corresponding 100 DIM milk yield of dairy cows housed on rubber or concrete flooring.

\section{Material and methods}

\section{Animal characteristics and treatment assignments}

The study was conducted at the Livestock Center of the Veterinary Faculty of the University Munich, Germany, between June 2006 and April 2009. Totally, a number of 102 cows entered the study. At the time of data analysis 91 cows had been observed during 139 lactation periods. All of them met the requirements of 100 days in milk (DIM), and at least one breeding (Table 1). A confirmed pregnancy at day 70 post inseminationem was detected in 109 of the 139 lactation periods. Fourteen cows were not pregnant after the third service, and 16 cows were between their first and third breeding without confirmed pregnancy (Table 2). Data of 11 cows were excluded from data analysis as cows were culled during the first 80 days after calving. The cows included into the study originated from two different breeds: German Holstein, German Fleckvieh and their different crossbreds. Cows of all genotypes were included in order to allow the comparison of a larger number of animals. The 91 cows included 10 cows in their first, second, and third lactation period, 28 cows in their first and second lactation period, and 53 cows in their first lactation period (=139 lactation periods; Table 1). The random number generator of Microsoft Excel 2003 (Microsoft Corporation, Redmond, WA, USA) helped to assign the cows into one of two groups in order to create groups with equal distribution of genotypes. Both groups were kept in the same cubicle housing system divided by a feeding alley into two parallel barns containing each 64 cubicles with identical dimensions. Both units were equipped with concrete slatted flooring and one automatic milking system (AMS). The slatted flooring of the experimental group barn was covered by precisely cut rubber mats (KURA S, KRAIBURG Elastik GmbH, Tittmoning, Germany). In this 
unit stall bed surfaces were comfortable rubber mattresses (type KKM, type KKE or type KSL, KRAIBURG Elastik GmbH, Tittmoning, Germany) which were renewed in 2002. The control group was housed on conventional concrete slatted flooring (CSF). In this unit, a daily - with chaffed straw - renewed straw-manure mixture served as bedding material. The CSF-unit was equipped with self-closing feeding head yokes for 54 cows. The rubber matted slatted flooring (RSF) unit had 28 single feeding troughs.

Table 1

Number of observed lactation periods within genotype and lactation numbers of cows on concrete and rubber flooring

\begin{tabular}{|c|c|c|c|c|c|c|c|c|c|}
\hline \multirow[t]{2}{*}{$\% G H$} & \multirow[t]{2}{*}{$\% F V$} & \multicolumn{4}{|c|}{ CSF } & \multicolumn{4}{|c|}{ RSF } \\
\hline & & 1. LP & 2. LP & 3. LP & Total & 1. LP & 2. LP & 3. LP & Total \\
\hline 0.00 & 100.00 & 10 & 3 & - & 13 & 11 & 3 & - & 14 \\
\hline 12.50 & 87.50 & - & - & - & 0 & 1 & 1 & - & 2 \\
\hline 25.00 & 75.00 & 10 & 5 & 3 & 18 & 12 & 6 & 3 & 21 \\
\hline 37.50 & 62.50 & 4 & 1 & - & 5 & 2 & 1 & - & 3 \\
\hline 50.00 & 50.00 & 3 & 3 & 1 & 7 & 4 & 2 & 1 & 7 \\
\hline 62.50 & 37.50 & 2 & - & - & 2 & 1 & - & - & 1 \\
\hline 68.75 & 31.25 & 1 & - & - & 1 & - & - & - & 0 \\
\hline 75.00 & 25.00 & 9 & 4 & - & 13 & 6 & 3 & 1 & 10 \\
\hline 87.50 & 12.50 & - & - & - & 0 & 2 & 1 & - & 3 \\
\hline 93.75 & 6.25 & - & - & - & 0 & 1 & - & - & 1 \\
\hline 100.00 & 00.00 & 7 & 2 & - & 9 & 5 & 3 & 1 & 9 \\
\hline \multicolumn{2}{|c|}{ Total } & 46 & 18 & 4 & 68 & 45 & 20 & 6 & 71 \\
\hline
\end{tabular}

\%GH: theoretical genetic proportion (\%) German Holstein, \%FV: theoretical genetic proportion (\%) German Fleckvieh, CSF: concrete slatted flooring group, RSF: rubber matted slatted flooring group, LP: lactation period

Table 2

Number of cows without positive pregnancy diagnosis excluded from data analysis of services per conception and days open

\begin{tabular}{lllllllllr}
\hline & \multicolumn{4}{c}{ CSF } & \multicolumn{4}{c}{ RSF } \\
& 1. LP & 2. LP & 3. LP & Total & 1.LP & 2. LP & 3. LP & Total \\
\hline $\begin{array}{l}\text { Cows not pregnant } \\
\text { after 3rd breeding }\end{array}$ & 3 & 2 & 3 & 8 & 5 & 1 & - & 6 \\
$\begin{array}{l}\text { Cows between 1st } \\
\text { and 3rd breeding }\end{array}$ & 4 & 1 & - & 5 & 3 & 6 & 2 & 11 \\
\hline
\end{tabular}

CSF: concrete slatted flooring group, RSF: rubber matted slatted flooring group, LP: lactation period

At the beginning of 2008 the feeding troughs were replaced by also self-closing feeding head yokes for 54 cows. A number of 50 cows on average were kept per unit during the time of data collection. Until October 2007, both groups were milked by an AMS Astronaut A2 (Lely Holding S.à r.l., Maassluis, The Netherlands). In October 2007, the AMS of the CSF group was replaced by an Astronaut A3 (Lely Holding S.à r.l., Maassluis, The Netherlands), and the AMS of the RSF group was replaced by a Voluntary Milking System (DeLaval International AB, Tumba, Sweden). Manure scraping in both units was performed by staff twice daily using a mobile, motordriven manure scraper. Since June 2008, manure scraping on the CSF has been performed by a Lely Discovery mobile barn cleaner (Lely Holding S.à r.l., Maassluis, The Netherlands). The reproduction management of the herd was as follows: The voluntary waiting period of the 
herd included 40 days after calving. That means cows were willingly not inseminated during this time even if they displayed oestrus. All cows were artificially inseminated during their first two services. In case of return after first service, cows received a GnRH injection at the time of second service. In case of third service, cows were mated naturally. Cows failing to be detected in oestrus during the first 120 DIM were treated with the first GnRH injection of the "Ovsynch" scheme around day 120 after calving and therefore, received a timed artificial insemination around day 130 relative to calving. For artificial insemination two German Holstein and two German Fleckvieh bulls, respectively, were frequently selected for the period of approximately one year, in order to perform rotational crossbreeding with the two breeds. Pregnancy status was determined using transrectal ultrasonography between day 28 and 45 and confirmed at day $70+$ relative to insemination. In all cows claw trimming was performed at day -21 , 150, and 305 relative to calving. Only in case drying-off was performed earlier than day 305 relative to calving, claws were trimmed at the time of drying-off. Twice daily, cows received a freshly mixed "partial" total mixed ration (TMR) calculated for $800 \mathrm{~kg}$ body weight (BW) and a milk yield of $32 \mathrm{~kg} / \mathrm{d}$, containing $4.0 \%$ fat and $3.4 \%$ protein using the Milliwin software package, version 6.0 (Verband Deutscher Oelmühlen e.V., Bonn, Germany) (Table 3).

Table 3

Composition of "partial" TMR and concentrate fed in the AMS

\begin{tabular}{lc}
\hline Composition & \% of DM \\
\hline Ingredients & \\
Grass silage & 24.4 \\
Corn silage & 33.7 \\
Corn & 4.3 \\
Rape seed meal & 4.3 \\
Soybean meal & \\
Sugar beet $\mathrm{f}$ & 8.4 \\
Concentrate & \\
$\quad$ Winter barley & 4.2 \\
$\quad$ Winter wheat & 4.2 \\
$\quad$ Sugar beet feed & 16.5 \\
Nutrients & \\
CP & 15.2 \\
Starch & 19.1 \\
NE & $7.1 \mathrm{MJ} / \mathrm{kg} \mathrm{DM}$ \\
Concentrate AMS & \\
Corn & 17.9 \\
Winter barley & 25.0 \\
Winter wheat & 28.6 \\
Soybean meal & 25.0 \\
Mineral and vitamin mix & 3.5 \\
\hline
\end{tabular}

TMR: total mixed ration, AMS: automatic milking system

The calculation of $\mathrm{NE}_{\mathrm{L}}$ followed the official feed regulation of Germany (Bundesministerium der Justiz 2007). In addition - depending on the daily milk yield (DMY) - cows obtained the following amounts of concentrate in the AMS: $15 \mathrm{~kg}$ DMY= $1 \mathrm{~kg}, 20 \mathrm{~kg}$ DMY $=2 \mathrm{~kg}, 25 \mathrm{~kg}$ $D M Y=3 \mathrm{~kg}, 30 \mathrm{~kg} D M Y=4 \mathrm{~kg}, 35 \mathrm{~kg} D M Y=5 \mathrm{~kg}, 40 \mathrm{~kg} D M Y=6 \mathrm{~kg}, 45 \mathrm{~kg} D M Y=7 \mathrm{~kg}, 50 \mathrm{~kg}$ $D M Y=8 \mathrm{~kg}, 55 \mathrm{~kg} D M Y=9 \mathrm{~kg}$, and $60 \mathrm{~kg} D M Y=10 \mathrm{~kg}$, respectively. The amount of concentrate 
was adapted weekly during the lactation. The mineral mix used in the TMR was Salvana 1135, Zell-Min (Salvana Tiernahrung GmbH, Klein-Offenseth Sparrieshoop, Germany). In addition, lactating cows had ad libitum access to the mineral lick feed Salvana 1191, Leckmasse Makro Typ 4 (Salvana Tiernahrung GmbH, Klein-Offenseth Sparrieshoop, Germany). Drying-off was performed 8 weeks before the expected calving of the following lactation period. During the far-off dry period cows were housed in a tie-stall, standing on rubber mattresses, and once daily received a far-off diet as shown in Table 4 supplemented by $150 \mathrm{~g}$ mineral feed per cow per day (Salvana 1104, Pre-Natal Beta; Salvana Tiernahrung GmbH, Klein-Offenseth Sparrieshoop, Germany). For the close-up dry period cows were reintegrated in the milking herd and therefore, again received the above mentioned "partial« TMR. During calving and the fresh-cow period (day 0-5), cows were separated from the herd and housed in a different tie-stall unit, standing on rubber mattresses, which were freshly littered with straw twice daily.

Table 4

Composition of the far-off diet

\begin{tabular}{ll}
\hline Composition & \% of DM \\
\hline Ingredients & \\
Grass silage & 75.9 \\
Barley straw & 24.1 \\
Nutrients & \\
CP & 12.7 \\
Starch & 0 \\
$\mathrm{NE}_{\mathrm{L}}$ & $5.5 \mathrm{MJ} / \mathrm{kg} \mathrm{DM}$ \\
\hline
\end{tabular}

\section{Study design and data collection}

Cows entered the study as heifers - 21 days before the expected day of their first calving. They belonged to one flooring system group for their whole productive life. For visual observation, oestrus was defined as "standing to be mounted", and detection has been done regularly (at least twice daily for half an hour) by the staff members. In addition, all cows received neck collars for identification including an activity counter. Until October 2007, activity measurement in both groups was performed by AM-activity-collars (Nedap-agri, Groenlo, The Netherlands). These devices counted all neck movements of the cow, raising by "1 " every 40 movements of the neck. After exchanging the AMS, the activity measurement of the CSF group was performed by the QWES-HR Infrared Detection System (SCR Engineers LTD, Netanya, Israel), and the activity measurement of the RSF group was performed by the DeLaval Activity Meter System (DeLaval, Tumba, Sweden). Both systems are based on acceleration sensors and therefore, represent mercury-free systems; both detect cow movements like walking, running, mounting, lying down, and rising. Additionally, both systems provide data about the current activity, the average activity and the likelihood of heat. Activity lists of both systems were checked daily by the staff members, and - in case of an electronic heat advice alone - cows were examined by a vet for heat additionally. All cows were compared for days to first breeding (DFB; $n=139$ ). Cows with confirmed pregnancies 70 days post inseminationem were compared additionally for services per conception (SC), and days open (DO; $n=109)$. Furthermore, heat detection rate (HDR) defined as number of cows inseminated 
between day 40 and $63 \times 100 /$ number of cows with and without insemination between day 40 and 63, and conception rate (first service), defined as number of cows pregnant after first service $\times 100 /$ number of all first services $\left(\mathrm{CR}_{1 \text { stservice }}\right)$ were calculated. Similarly, in order to evaluate data of the same cows for milk yield the 100 DIM milk yield, originating from the official milk performance testing of the "Landeskuratorium der Erzeugerringe für tierische Veredelung in Bayern e.V.", was compared for milk $\mathrm{kg}(\mathrm{kgM})$, fat $\mathrm{kg}(\mathrm{kgF})$, fat \% (\%F), protein $\mathrm{kg}(\mathrm{kgP})$, and protein \% (\%P; $\mathrm{n}=139)$. Sample collection frequency was 11 per year. As the 100 DIM milk yield is only given officially for first calving cows, 100 DIM milk yields for older cows were calculated linearly from the data of the performance testing closest to $100 \mathrm{DIM}$.

\section{Statistical analyses}

The SAS 9.2 package (SAS Institute Inc., Cary, NC, USA) provided the tools for data analysis using a mixed model procedure with the following structure for days to first breeding, days open, and services per conception:

$$
y_{i j k l m n}=\mu+H_{i} \times F_{j}+S_{k}+L_{l}+B M_{i j k l m n}+a_{m}+e_{i j k l m n}
$$

and for the milk yield:

$$
y_{i j k l m n}=\mu+H_{i} \times F_{j}+S_{k}+L_{l}+a_{m}+e_{i j k l m n}
$$

where $y_{i j k m n}$ is the observation, $\mu$ is the expected value of $y_{1} H_{i} \times F_{j}$ is the interaction $H$ is the breed proportion \% German Holstein $(i=1,2,3,4,5,6,7,8,9,10,11) \times F=$ breed proportion $\%$ German Fleckvieh $(j=1,2,3,4,5,6,7,8,9,10,11)(i \times j), S_{k}$ is the flooring $(k=1,2), L$, is the lactation number $(I=1,2,3), B M_{i j k m n}$ is the milk yield, $a_{m}$ is the age at first calving $(m=1, \ldots, 77)$, and $e_{i j k l m n}$ is the residual error. The model included as fixed effects the flooring, the lactation period, and the breed proportions (genotype) of the cows. Furthermore, the age at first calving was included as a random effect and the milk yield as covariable.

\section{Results}

The results of the data analysis of the reproduction traits are shown in Table 5. The evaluation showed significant differences between the two groups regarding DFB and DO. Cows housed on RSF had significantly less DFB and DO than cows housed on CSF. SC was not significantly different comparing the two groups. The HDR and $\mathrm{CR}_{1 \text { stservice }}$ in the RSF group were $54.9 \%$ and $39.4 \%$, and $27.9 \%$ and $29.4 \%$ in the CSF group, respectively. The results of the data analysis of the 100 DIM milk yield are shown in Table 6. Amounts of milk, fat, and protein showed no significant differences. Likewise, the percentage of fat showed no difference between the two groups. Alone the average percentage of protein showed a statistically significant difference between the two groups. The results of the fixed effects within the model for DFB, DO, SC, and for the milk traits are shown in Table 7. 
Table 5

Least squares means, standard errors of estimation, and significance of reproduction traits in the concrete slatted flooring group and rubber-matted slatted flooring group

\begin{tabular}{lccc}
\hline Reproduction traits & CSF & RSF & $P$-value \\
\hline Days to first breeding & $94.6 \pm 6.5$ & $76.8 \pm 6.1$ & $<0.01$ \\
Services per conception & $1.7 \pm 0.3$ & $1.5 \pm 0.3$ & 0.267 \\
Days open & $138.4 \pm 15.3$ & $98.8 \pm 14.5$ & $<0.01$ \\
\hline
\end{tabular}

CSF: concrete slatted flooring group, RSF: rubber matted slatted flooring group

Table 6

Least squares means, standard errors of estimation, and significance of the 100 DIM milk yield in the concrete slatted flooring group and rubber-matted slatted flooring group

\begin{tabular}{lccc}
\hline Milk yield & CSF & RSF & $P$-value \\
\hline Milk, kg & $3136.5 \pm 125.9$ & $3088.9 \pm 117.4$ & 0.630 \\
Fat, kg & $127.1 \pm 5.5$ & $122.8 \pm 5.1$ & 0.344 \\
Fat, $\%$ & $4.03 \pm 0.13$ & $3.97 \pm 0.12$ & 0.581 \\
Protein, kg & $100.4 \pm 4.0$ & $101.4 \pm 3.8$ & 0.762 \\
Protein, $\%$ & $3.20 \pm 0.04$ & $3.30 \pm 0.04$ & $<0.01$ \\
\hline
\end{tabular}

CSF: concrete slatted flooring group, RSF: rubber matted slatted flooring group

Table 7

Table of variance analysis with results of the F-test ( $P$-value)

\begin{tabular}{lccc}
\hline Traits & Flooring & $\begin{array}{c}\text { Fixed effects } \\
\text { Genotype }\end{array}$ & Lactation period \\
\hline Days to first breeding & 0.0042 & 0.0254 & 0.9323 \\
Days open & 0.0007 & 0.0266 & 0.0310 \\
Services per conception & 0.7273 & 0.7333 & 0.1774 \\
Milk Yield & 0.6304 & 0.0032 & $<0.0001$ \\
Fat Yield & 0.3592 & 0.0061 & $<0.0001$ \\
Fat Content & 0.5813 & 0.7169 & 0.6020 \\
Protein Yield & 0.8804 & 0.2197 & $<0.0001$ \\
Protein Content & 0.0040 & 0.1435 & 0.3328 \\
\hline
\end{tabular}

\section{Discussion}

The 120 cow dairy herd of the Livestock Center of the University Munich includes cows of different genotypes: purebred German Holstein, purebred German Fleckvieh, and various rotational crossbreeding combinations of the two breeds including the F1 generation. All cows entered the study as heifers, in order to guarantee the same metabolic load for all animals. The cows were only housed on one flooring system during their whole productive lifetime, except for calving and the far-off dry period. During these periods all cows were kept in the same tie-stalls on rubber mattresses with or without straw bedding. Additionally, both groups were subject to the same climatic, management, and feeding conditions except one difference, regarding the - until spring 2008 existing - ratio of feeding space per cow between the two groups. But Friend et al. (1977) demonstrated that in order to avoid a decreasing feed intake, a 1:1 cow-to-feeding place ratio is not required, if a TMR is available throughout the whole day. Furthermore, a slightly reduced cow-to-feeding place ratio is negligible in herds 
milked by automatic milking systems, as the cows do not have the same circadian rhythm. Automatic milking systems require milking $24 \mathrm{~h}$ a day. That means, even when fresh food is provided some cows are waiting in front of the AMS or are lying down in the stalls. In addition, regarding the housing conditions, it could be argued that in contrast to the rubber mattresses the straw manure mix stalls offer a higher level of comfort. Both kinds of stalls, however, had identical dimensions and the mattresses were of very high quality. As cows do not show any preferences in stall use between deep stalls or mattresses but in soft or hard (Norring et al. 2010), and in wet or dry surfaces (Fregonesi et al. 2007), it could be assumed that only the daily straw littering of the straw manure mix stalls slightly favours the comfort of the CSF group's stalls. Therefore, slightly less comfortable lying conditions were provided in the RSF group. In summary, however, comparable housing conditions were provided for both groups, in order to evaluate only the effect of different flooring systems on fertility and milk yield. The reproductive performance of cows is related to numerous factors, especially to claw disorders (Sogstad et al. 2006, Walker et al. 2008, Walker et al. 2010). Particularly, it is difficult to distinguish among cause-and-effect relationships of flooring, fertility and lameness. Until today, as mentioned above, the effect of rubber flooring on the incidence of claw diseases is discussed controversially. Previous studies, however, show that soft flooring compared with concrete flooring does not affect the incidence of clinical lameness if claws are trimmed frequently and functionally (Kremer et al. 2007). Thus, as all cows received the same claw trimming interval relative to calving, it was assumed that no differences regarding clinical lameness affected the evaluated fertility traits. Cows of both groups also were subject to the same reproductive management scheme and were inseminated with semen of the same bulls by the same staff members. Almost the same number of cows did not become pregnant after the third service (CSF: 8; RSF: 6). Anyhow, the evaluated data showed significantly less DFB in the RSF group compared with the CSF group, while flooring had the highest effect within the statistical model (Table 7). The difference between the two groups was 17.8 days, which does not only mean a statistically significant, but also a biologically relevant, earlier detection of cows in heat if housed on rubber flooring. This finding is also supported by the calculated HDR, which was almost double in the RSF group compared with the CSF group. These results may partly be caused by the preference of oestrous cows for mounting other cows on rubber rather than on concrete flooring (Vailes \& Britt 1990, Platz et al. 2008), and therefore providing the higher chance of being detected visually. Heat detection, however, was also performed by activity meters and not only by visual observation during this study. This fact supports the hypothesis that cows on rubber flooring show actually an oestrous cycle earlier post partum than do cows on concrete flooring. Beyond that, the results of the calculated $\mathrm{CR}_{\text {1stservice }}$ confirmed also higher fertility on RSF, because the $\mathrm{CR}_{\text {1stservice }}$ in cows housed on RSF was $10 \%$ higher than in those housed on CSF. Conception, however, requires a sufficient and complete oestrous cycle. Several studies confirm that the first ovulation post partum occurs 10-15 days after the nadir of negative energy balance (Butler \& Smith 1989, Zurek et al. 1995). The timing and the magnitude of the negative energy balance mostly depend on the dry matter intake (DMI) relative to the milk performance of the cows. The amount of DMI depends - besides milk performance - also on the welfare and overall-health of the cows, as stress directly reduces the feed intake (Ingvartsen \& Andersen 2000). In the context of this study, no data were available which could show that the type of flooring 
affects DMI in dairy cows. Several studies, however, confirm the connection between the energy balance post partum and the onset of the oestrous cycle post partum (Lucy et al. 1991, Zurek et al. 1995). Therefore, the current study insistently suggests the question, if a higher level of comfort caused by the rubber flooring could increase the DMI of dairy cows by higher feed intake during the time spent at the feed bunk resulting in an earlier onset of the oestrous cycle post partum and a higher conception rate.

Furthermore, DO showed a significant difference of 39.6 days between the RSF and the CSF group, and within the statistical model flooring had again the highest effect (Table 7). This difference means a considerable reduction of the expected calving interval of cows housed on rubber. Data analysis was based on confirmed pregnancies on day 70 after insemination. The day 70 post inseminationem was chosen in order to minimise the risk of loosing pregnancies by early or late embryonic death, because its highest incidence in dairy cows occurs between day 28 and 45 of pregnancy (Fricke et al. 1998, Vassilev et al. 2005), and only $3.4 \%$ of pregnancies are lost after day 70 (Vasconcelos et al. 1997). Discussing the results regarding DFB, HDR and DO it has to be taken into account, that different heat detection systems were used during half of the study time. Preliminary results of the same study, however, including only data until the exchange of the AMS and the heat detection systems showed already a remarkable difference between the two groups regarding DO based on only 30 cows (CSF $99 \mathrm{~d} /$ RSF $60 \mathrm{~d}, P=0.06$, Kremer et al. 2008). Compared with the final results, almost the same difference regarding $\mathrm{DO}$ has been found between the two groups using identical heat detection systems. Therefore, it can be assumed, that the differences regarding DO and accordingly also DFB and HDR are not caused by the use of different heat detection systems or AMS, but by flooring. Hady et al. (1994) calculated the economic impact of the reproductive performance of a dairy herd on the farm profitability. They conclude that decreasing days open and days to first service and increasing the efficiency of detected oestrus along with an increased conception rate can provide remarkable higher revenues. Thus, equipping loose housing systems with rubber flooring can increase farming profitability by achieving earlier pregnancies after the expiry of the voluntary waiting period.

Furthermore, a very important reproduction trait is the number of SC. During the current study the number of SC was not significantly affected by flooring. SC values of both groups represent a good reproductive performance, as González-Recio et al. (2004) estimate similar profitability for cows who needed 1 or $2 \mathrm{SC}$. Only cows requiring more than 3 inseminations decreased the profit by $>205$ US\$ per year and cow. The fact that the SC did not differ between the groups but the number of DO did by 39.6 days leads to the assumption that one cycle after the first breeding in cows on CSF has not been used for breeding. This could again result from the fact that cows on concrete flooring are more reluctant to show heat than cows on rubber flooring (Vailes \& Britt 1990, Platz et al. 2008).

Additionally the milk yield of the first 100 DIM of all cows was also evaluated by the mixed model procedure as for fertility traits. Performance data showed no significant difference regarding $\mathrm{kgM}, \mathrm{kgF} \% \mathrm{~F}$, and $\mathrm{kgP}$ between the two groups. The percentage of protein, however, was significantly higher in the RSF group compared with the CSF group. These results regarding milk performance are similar as those of Kremer et al. $(2006,2007)$ or Pempek \& Botheras (2009) who could not detect any increase in milk yield in dairy cows housed on rubber compared with those housed on concrete flooring. The significant higher percentage of protein has to be 
assessed carefully. Furthermore, no significant difference regarding the amount of milk (kgM) and protein $(\mathrm{kgP})$ was found between the two groups, but the RSF group yielded slightly less $\mathrm{kgM}(-47.6)$ and more $\mathrm{kgP}(+1.0)$ than did the CSF group. This leads to the assumption that the significantly higher percentage of protein in the RSF group is a statistically confirmed but in the context of this study biologically less relevant result. Therefore, it cannot be concluded that housing dairy cows on rubber flooring strictly increases milk protein content. In general, milk yield anecdotally is often reported to be improved on rubber flooring. Until today no scientific evidence has been published regarding this statement. The milk yield of dairy cows is mainly influenced by their genetics, the time spent lying, and their nutrient supply. Several studies provide evidence that cows housed on rubber flooring spend less time lying and more time standing in the alleys or at the feed bunk compared with those housed on concrete flooring (Fregonesi et al. 2004, Tucker et al. 2006). The fact that cows housed on rubber flooring spend less time lying and more time standing but still yield the same amount of milk, implies that a lack of lying time could be compensated by a higher feed intake during the time spent at the feed bunk, and therefore, no decrease regarding the milk yield was detected. This would also be in agreement with the hypothesis of the earlier onset of the oestrous cycle likely caused by a higher DMI and therefore, less metabolic stress during the period of negative energy balance when housed on rubber flooring.

In conclusion, cow comfort is an important issue in dairy farming. Health and welfare of dairy cows are vitally important to ensure their longevity and long-term productivity in order to resist the high financial pressure. Equipping the alleys of loose housing systems for dairy cows with rubber mats increases the level of comfort. The results of this study showed that the reproductive performance of dairy cows regarding number of days to first breeding, days open, and heat detection and conception rate (first service) was improved on rubber flooring compared with concrete flooring in loose housing systems. The cows housed on rubber flooring were approximately 18 days earlier detected for first breeding post partum and had approximately 40 days less open, although both groups underwent the same voluntary waiting period. More than half of the cows housed on rubber flooring were detected for heat during the first 23 days after their voluntary waiting period had passed. In contrast, only slightly more than a quarter of the cows were detected for heat during this time when housed on concrete flooring. In addition, almost $40 \%$ of all first services in cows housed on rubber flooring resulted in pregnancy while only almost $30 \%$ did in cows housed on concrete flooring. Therefore, it could be concluded that cows on rubber flooring show an earlier onset of regular oestrus behaviour which results in an earlier pregnancy and in conclusion a shorter calving interval. The number of services per conception was not influenced by flooring. An early and regular oestrous cycle is the major limitation to achieving a pregnancy, and the study provided evidence that rubber flooring improves the economically sensible fertility trait of calving interval by earlier pregnancy and fewer days open after the expiry of the voluntary waiting period. Furthermore, regarding the milk yield, it could be shown that cows housed on rubber flooring do not yield less milk, although it is cited in the literature that cows spend more time walking and standing in the alleys and at the feed bunk at the expense of lying when housed on rubber. Additionally, the study raises the question if rubber flooring, based on a higher level of welfare, increases dry matter intake and therefore, affects fertility by influencing the negative energy balance in cows housed on rubber. 


\section{Acknowledgements}

We thank the Gummiwerk Kraiburg, Tittmoning, Germany, for equipping stalls and alleys of one dairy unit of the Livestock Center Oberschleissheim with the appropriate rubber mats.

\section{References}

Allaire FR, Gibson JP (1992) Genetic value of herd life adjusted for milk production. J Dairy Sci 75, 1349-1356

Benz B (2002) [Rubber mats for concrete slatted flooring in loose housing systems]. Thesis, Stuttgart, University Hohenheim, Germany [in German]

Boyle LA, Mee JF, Kiernan PJ (2007) The effect of rubber versus concrete passageways in cubicle housing on claw health and reproduction of pluriparous dairy cows. Appl Anim Behav Sci 106, 1-12

Bundesministerium der Justiz (2007) [Feed regulation, appendix 4, part 1: Estimating equations for calculating the energy value of compound feeds]. BGBI. I-22, 841-842 [in German]

Butler WR, Smith RD (1989) Interrelationships between energy balance and postpartum reproductive function in dairy cattle. J Dairy Sci 72, 767-783

Fjeldas T, Sogstad ÅM, Østerås O (2011) Locomotion and claw disorders in Norwegian dairy cows housed in freestalls with slatted concrete, solid concrete, or solid rubber flooring in the alleys. J Dairy Sci 94, 12431255

Fregonesi JA, Tucker CB, Weary DM, Flower FC, Vittie T (2004) Effect of rubber flooring in front of the feed bunk on the time budgets of dairy cattle. J Dairy Sci 87, 1203-1207

Fregonesi JA, Veira DM, von Keyserlingk MAG, Weary DM (2007) Effects of bedding quality on lying behavior of dairy cows. J Dairy Sci 90, 5468-5472

Fricke PM, Guenther JN, Wiltbank MC (1998) Efficacy of decreasing the dose of GnRH used in a protocol for synchronization of ovulation and timed Al in lactating dairy cows. Theriogenology 50, 1275-1284

Friend TH, Polan CE, McGilliard ML (1977) Free stall and feed bunk requirements relative to behavior, production and individual feed intake in dairy cows. J Dairy Sci 60, 108-116

González-Recio O, Pérez-Cabal MA, Alenda R (2004) Economic value of female fertility and its relationship with profit in Spanish dairy cattle. J Dairy Sci 87, 3053-3061

Hady PJ, Lloyd JW, Kaneene JB, Skidmore AL (1994) Partial budget model for reproductive programs of dairy farm businesses. J Dairy Sci 77, 482-491

Ingvartsen KL, Andersen JB (2000) Integration of Metabolism and Intake Regulation: A Review Focusing on Periparturient Animals. J Dairy Sci 83, 1573-1597

Kremer PV, Nüske S, Scholz AM, Förster M (2006) [Effect of soft flooring in free stalls on milk yield, fat, protein and somatic cell counts in dairy cattle]. Arch Tierz 49, 250-258 [in German]

Kremer PV, Nüske S, Scholz AM, Förster M (2007) Comparison of claw health and milk yield in dairy cows on elastic or concrete flooring. J Dairy Sci 90, 4603-4611

Kremer PV, Scholz AM, Nüske S, Förster M (2008) Reproduction traits in dairy cows on elastic or concrete flooring. In: Proc World Buiatric Congress, 6-11 July, Budapest, Hungary, 936, 213

Leitch HW (1994) Comparison of international selection indices for dairy cattle breeding. Interbull Bull 10

Lucy MC, Staples CR, Michel FM, Thatcher WW (1991) Energy balance and size and number of ovarian follicles detected by ultrasonography in early postpartum dairy cows. J Dairy Sci 74, 473-482

Nebel RL, McGilliard ML (1993) Interactions of high milk yield and reproductive performance in dairy cows. J Dairy Sci 76, 3257-3268

Norring M, Manninen E, de Passillé AM, Rushen J, Saloniemi H (2010) Preferences of dairy cows for three stall surface materials with small amounts of bedding. J Dairy Sci 93, 70-74 
Pempek J, Botheras N (2009) Effect of rubber flooring in a freestall dairy barn on cow behavior and milk production. J Dairy Sci 92, E-Suppl 1, 7. Joint Annual Meeting of ADSA-CSAS-ASAS, 12-16 July, Montreal, Canada

Platz S, Ahrens F, Bendel J, Meyer HH, Erhard MH (2008) What happens with cow behavior when replacing concrete slatted floor by rubber coating: a case study. J Dairy Sci 91, 999-1004

Sørensen AC, Lawlor T, Ruiz F (2007) A survey on fertility in the Holstein populations of the world In: Proc. Int Conf Fertility in Dairy Cows, 30-31 August, Liverpool Hope University, Liverpool, UK, 1:17

Sogstad ÅM, Østeras O, Fjeldaas T (2006) Bovine claw and limb disorders related to reproductive performance and production diseases. J Dairy Sci 89, 2519-2528

Tucker CB, Weary DM, de Passillé AM, Campbell B, Rushen J (2006) Flooring in front of the feed bunk affects feeding behavior and use of freestalls by dairy cows. J Dairy Sci 89, 2065-2071

Vailes LD, Britt JH (1990) Influence of footing surface on mounting and other sexual behaviors of estrual Holstein cows. J Anim Sci 68, 2333-2339

Vanegas J, Overton M, Berry SL, Sischo WM (2006) Effect of rubber flooring on claw health in lactating dairy cows housed in free-stall barns. J Dairy Sci 89, 4251-4258

Vasconcelos JLM, Silcox RW, Lacerda JA, Pursley JR, Wiltbank MC (1997) Pregnancy rate, pregnancy loss and response to heat stress after $\mathrm{Al}$ at two different times from ovulation in dairy cows. Biol Reprod 56 Suppl 1,140

Vassilev N, Yotov S, Dimitrov F (2005) Incidence of early embryonic death in dairy cows. Trakia J Sci3, 62-64

Walker SL, Smith RF, Jones DN, Routly JE, Morris MJ, Dobson H (2010) The effect of a chronic stressor, lameness, on detailed sexual behaviour and hormonal profiles in milk and plasma of dairy cattle. Reprod Domest Anim 45, 109-17

Walker SL, Smith RF, Routly JE, Jones DN, Morris MJ, Dobson H (2008) Lameness, activity time-budgets, and estrus expression in dairy cattle. J Dairy Sci 91, 4552-4559

Windig JJ, Calus MPL, Veerkamp RF (2005) Influence of herd environment on health and fertility and their relationship with milk production. J Dairy Sci 88, 335-347

Zurek E, Foxcroft GR, Kennelly JJ (1995) Metabolic status and interval to first ovulation in postpartum dairy cows. J Dairy Sci 78,1909-1920

Received 27 September 2011, accepted 26 April 2012.

Corresponding author:

Prisca V. Kremer

email: prisca.kremer@hswt.de

Faculty of Agriculture, University of Applied Sciences Weihenstephan - Triesdorf, Steingruberstr. 2, 91746 Weidenbach, Germany 